\title{
New Insights into the Liver-Visceral Adipose Axis During Hepatic Resection and Liver Transplantation
}

\author{
María Eugenia Cornide-Petronio ${ }^{1,+} \mathbb{C}^{\mathbb{C}}$, Mónica B. Jiménez-Castro ${ }^{1,+}+\mathbb{C}$, Jordi Gracia-Sancho ${ }^{2,3}$ \\ and Carmen Peralta $1,3, *$ (iD \\ 1 Institut d'Investigacions Biomèdiques August Pi I Sunyer (IDIBAPS), 08036 Barcelona, Spain; \\ cornide@clinic.cat (M.E.C.-P.); monicabjimenez@hotmail.com (M.B.J.-C.) \\ 2 Liver Vascular Biology Research Group, Barcelona Hepatic Hemodynamic Laboratory IDIBAPS, \\ 08036 Barcelona, Spain; jgracia@clinic.cat \\ 3 Centro de Investigación Biomédica en Red de Enfermedades Hepáticas y Digestivas (CIBERehd), \\ 08036 Barcelona, Spain \\ * Correspondence: cperalta@clinic.cat; Tel.: +34-93-227-5400 \\ + These authors equally contributed to this work.
}

Received: 11 July 2019; Accepted: 17 September 2019; Published: 18 September 2019

\begin{abstract}
In the last decade, adipose tissue has emerged as an endocrine organ with a key role in energy homeostasis. In addition, there is close crosstalk between the adipose tissue and the liver, since pro- and anti-inflammatory substances produced at the visceral adipose tissue level directly target the liver through the portal vein. During surgical procedures, including hepatic resection and liver transplantation, ischemia-reperfusion injury induces damage and regenerative failure. It has been suggested that adipose tissue is associated with both pathological or, on the contrary, with protective effects on damage and regenerative response after liver surgery. The present review aims to summarize the current knowledge on the crosstalk between the adipose tissue and the liver during liver surgery. Therapeutic strategies as well as the clinical and scientific controversies in this field are discussed. The different experimental models, such as lipectomy, to evaluate the role of adipose tissue in both steatotic and nonsteatotic livers undergoing surgery, are described. Such information may be useful for the establishment of protective strategies aimed at regulating the liver-visceral adipose tissue axis and improving the postoperative outcomes in clinical liver surgery.
\end{abstract}

Keywords: adipose tissue; liver; inflammation; steatosis; liver resection; liver transplantation; lipectomy

\section{Introduction}

In the last decade, adipose tissue has emerged as an essential and highly active metabolic and endocrine organ [1-3]. The basic function of adipocytes is to take up free fatty acids (FFA) from circulating lipoprotein complexes and esterify them into triacylglycerides [4]. During times of metabolic demand, hydrolysis of triacylglyceride releases FFA to generate adenosine triphosphate (ATP) [5]. These adipocyte processes, termed lipogenesis and lipolysis, respectively, are primarily governed through hormonal pathways [6]. However, one of the most important characteristics of adipose tissue is its function in whole-body energy homeostasis, mediated principally through the endocrine system [4]. Adipose tissue expresses and secretes a variety of bioactive molecules, known as adipokines, which may exert their effects in adipose tissue and in other organs [7]. Adipokines include leptin, interleukin (IL)-6, other cytokines, adiponectin, complement components, adipsin, plasminogen activator inhibitor-1 (PAI-1), and proteins of the renin-angiotensin system, among others [7]. Collectively, adipokines modulate the crosstalk between adipose tissue and other metabolic organs, including the liver [8]. 
Thus, adipokines directly target the liver through the portal vein [9] and have significant effects on liver diseases [4].

The hypoxia and subsequent oxygen delivery restoration to the liver, namely, hepatic ischemia-reperfusion (I/R), is one of the major pathophysiological events and causes of morbidity and mortality in liver resections and transplantation, being more evident in the presence of hepatic steatosis [10-14]. Despite the attempts to solve this issue, hepatic $\mathrm{I} / \mathrm{R}$ is an unresolved problem in clinical practice [15]. The cellular mechanisms involved in liver I/R injury are numerous and complicated [14], which led to discrepancies in our understanding of this pathology [16]. For instance, the mechanisms underlying I/R injury in conditions of cold ischemia associated with liver transplantation (LT) are different from those that occur in conditions of warm ischemia associated with liver resections. In addition, hepatic steatosis is associated with an increased postoperative complication index and mortality after liver resection and transplantation, and the mechanisms responsible for hepatic damage and regenerative failure are different in steatotic versus nonsteatotic livers [15]. The investigations focused on the role of adipose tissue are of clinical and scientific relevance since the prevalence of obesity ranges from $24-45 \%$ of the population and consequently is expected to increase the number of steatotic livers submitted to surgery, which poorly tolerate $\mathrm{I} / \mathrm{R}$ damage, resulting in liver dysfunction and regenerative failure [17-23]. In addition, it has been reported that adipose tissue exerts both pathological or, on the contrary, protective effects on damage and regenerative response [24]. It should be noted that functional differences between lean and obese adipose tissue have been extensively described [25-27] and summarized, as seen in Figure 1. Briefly, adipose tissue from lean individuals is a connective tissue of low density with small insulin-sensitive adipocytes that secrete adipokines involved in energy homeostasis, angiogenesis, and antioxidant processes. However, the rigidity of adipose tissue from obese individuals is caused by the increment of connective fiber content. Hypertrophic insulin-resistant adipocytes secrete different inflammatory mediators, resulting in adipose tissue dysfunction, impaired angiogenesis, and cell death [25-27]. Moreover, obesity induces changes in the secretion of adipokines from adipose tissue to the circulation [28-30] and increases the inflammatory response and oxidative stress in adipose tissue [31-35]. Therefore, investigations focused on evaluating the liver-adipose tissue axis in steatotic and nonsteatotic livers subjected to hepatic resections or transplants are highly useful in the establishment of specific therapies to prevent both hepatic I/R injury and regenerative failure in liver surgery.

In the first part of this review, we highlight the actual knowledge of the crosstalk between the adipose tissue and the liver during liver surgery. In addition, the different experimental models and pharmacological strategies aimed at regulating potential dysfunctions in the adipose tissue-liver axis in liver surgery are presented, focusing on the strengths and limitations. Clinical results on the role of adipose tissue in the postoperative outcomes after liver surgery are also discussed. 


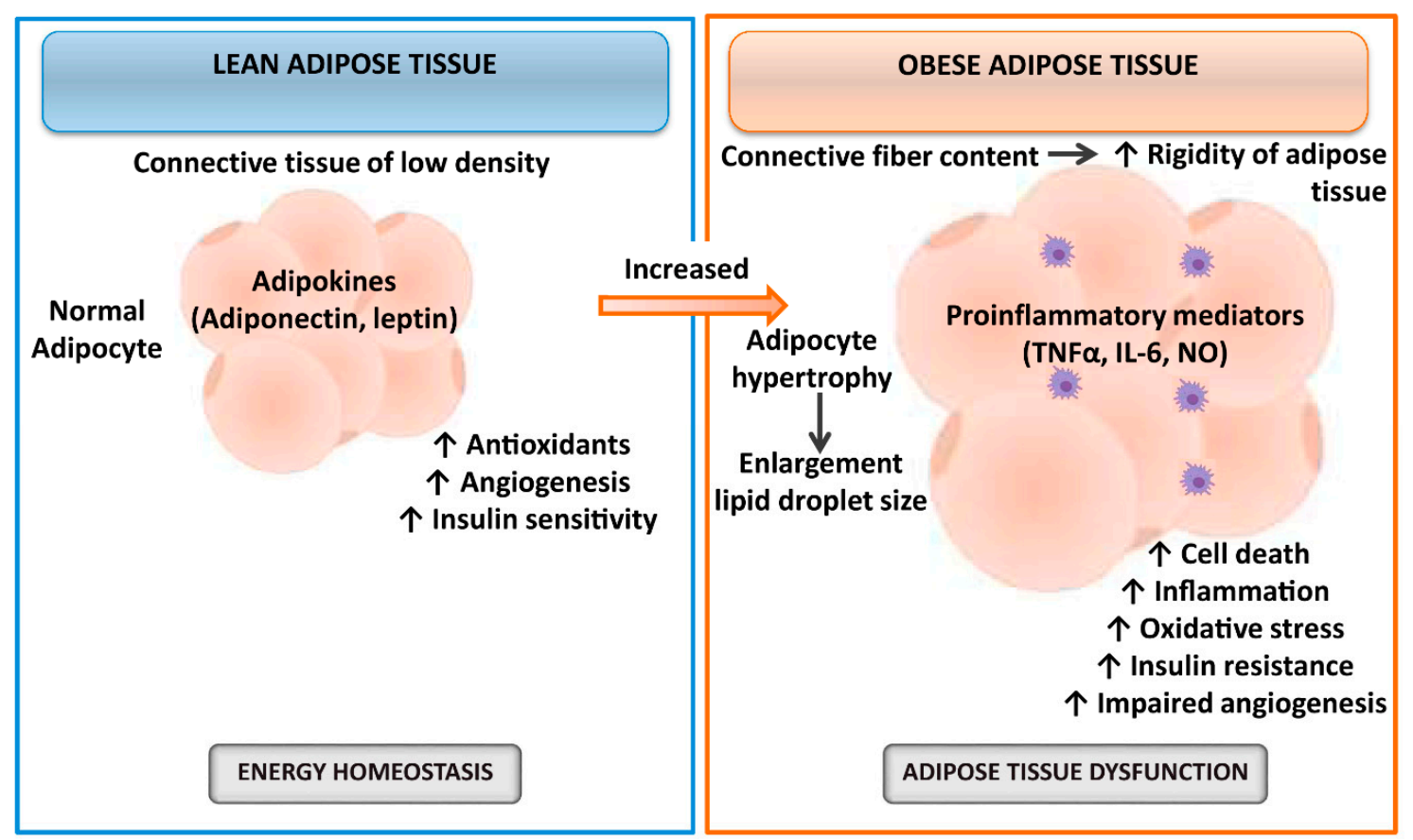

Figure 1. Schematic illustration of functional differences between lean and obese adipose tissue.

Abbreviations: IL, interleukin; NO, nitric oxide; $\mathrm{TNF} \alpha$, tumor necrosis factor $\alpha$.

\section{Relevance of Adipose Tissue in Experimental Models of Liver Resection}

Crosstalk between the adipose tissue and the liver is an important event both in the physiological function of the liver and in the development of liver diseases [4]. Indeed, adipose tissue inflammation is a well-recognized sign of obesity [36,37], one of its major consequences being the alteration of the secretion of adipokines that drain to the liver via the portal vein, a notion known as the "portal theory" [37-39]. This dysfunctional adipose tissue-liver axis is supported by the specific disruption in adipocytes of inflammatory mediators (apoptosis antigen 1 or cluster of differentiation 95; Fas/CD95) and/or inflammatory signals (c-Jun N-terminal kinase-1, JNK1) in different mouse models, resulting in protection against hepatic steatosis [40,41].

It has been suggested that lipids are the preferred energy substrate for nonsteatotic livers in conditions of partial hepatectomy (PH) without I/R [42-44]. Briefly, hypoglycemia that follows PH induces catabolism of peripheral adipose stores followed by hepatic accumulation of systemically derived fat and subsequent liver regeneration [45-47]. This is supported by the fact that glucose administration could block the mobilization of fatty acids from adipose tissue by the liver to obtain energy [48]. Parameters of lipid metabolism have been reported during hepatic regeneration: esterification rate of fatty acids from adipose tissue is higher and lipogenesis is raised [49,50]. In fact, the remaining liver after $\mathrm{PH}$ expresses the lipoprotein lipase, which could take up fatty acids from circulating triacylglycerides [51]. Moreover, different studies have described that mice lacking lipid metabolism-associated genes have reduced hepatic adipogenesis and regeneration liver failure [52,53]. In line with this, the surgical relevance of the lipid lowering effect of omega- 3 fatty acids has been studied in steatotic livers in the setting of hepatic I/R injury without PH [54] or in PH without I/R [55] (Figure 2). It should be noted that the process of liver regeneration requires careful regulation of lipid accumulation. In fact, Yang et al. suggested that Smad interacting protein-1 (SIP1) (a key factor linked to the transforming growth factor- $\beta$ (TGF- $\beta$ ), bone morphogenetic protein (BMP), and Wnt signaling pathways) is one of the mechanisms involved in the hepatic lipid accumulation and, consequently, in the process of liver regeneration under PH without I/R [56] (Figure 2). It is well known that in order for the liver to regenerate, the provision of fatty acids, phospholipids, and cholesterol to the liver is essential for the maintenance of the rate of formation of the membranes of dividing liver 
cells $[50,51]$. On the other hand, important questions for steatotic livers arise from these data since further studies will be required to elucidate whether steatosis may be reduced to avoid the vulnerability of steatotic livers to $\mathrm{I} / \mathrm{R}$ and the regenerative failure, or instead if drugs aimed at increasing the levels of hepatic triglycerides should be used during surgery and thus conserve the energy required for liver regeneration.

The studies mentioned above in liver surgery have been reported in settings of I/R without $\mathrm{PH}$ or in $\mathrm{PH}$ without I/R. However, it should be noted that in the clinical setting, $\mathrm{PH}$ is usually performed under vascular occlusion. Thus, if our aim is the establishment of new protective strategies in the clinical setting of hepatic resection, the experimental conditions used at the bench-side should simulate as close as possible the clinical reality. Fortunately, some studies have evaluated the contribution of adipose tissue to liver injury and regeneration in PH with I/R conditions. Firstly, Mendes-Braz et al. demonstrated that the relevance of adipose tissue in hepatic damage and regeneration depends on the type of liver [57]. In this sense, adipose tissue is not required for the regeneration of nonsteatotic livers subjected to $\mathrm{PH}$ with $\mathrm{I} / \mathrm{R}$. In contrast, it is necessary to promote regeneration and reduce injury in steatotic livers. Taking these data into account, glucose or lipid emulsion was administered in obese and lean animals undergoing $\mathrm{PH}+\mathrm{I} / \mathrm{R}$. Glucose or lipid treatment in nonsteatotic livers protected against hepatic damage and regenerative failure. In obese animals, glucose treatment did not protect steatotic livers against damage but improved their regeneration. However, lipid treatment conferred protection against damage and regenerative failure [57]. Mendes-Braz et al. suggest that in addition to the function of adipose tissue as a lipid precursor for new membrane synthesis, the requirement of systemic adipose stores during regeneration of steatotic livers might be based on the endocrine role of adipose tissue as a source of different adipokines, which are essential signals for liver regeneration [57].

In addition to the studies related to the role of adipose tissue as a source of energy substrates or inductors of hepatic lipid accumulation, other studies have investigated the potential contribution of adipose tissue as a source of bioactive molecules such as visfatin, cortisol, and soluble forms of the VEGF receptor 1 (sFlt1).

Elias-Miró et al. found the injurious effects of visfatin in $\mathrm{PH}$ with $\mathrm{I} / \mathrm{R}$ and that steatotic livers were more vulnerable to upregulated visfatin than nonsteatotic livers. The administration of visfatin exacerbated damage and regenerative failure in steatotic livers following PH with $\mathrm{I} / \mathrm{R}$. Treatment with resistin maintained low levels of visfatin in steatotic livers by blocking its hepatic reuptake from adipose tissue and consequently prevented the injurious effects of visfatin on hepatic damage and regenerative failure [58] (Figure 2).

In pathologic states, adipose tissue may also secret a range of hormones including cortisol, which may be taken up from the circulation by the liver [1,59]. Cornide-Petronio et al. reported that in instances of PH with $\mathrm{I} / \mathrm{R}$, the contributory potential of adipose tissue (as a cortisol source) is dependent on baseline liver status (steatotic versus nonsteatotic livers). In such surgical conditions, the authors found that cortisol levels in adipose tissue and liver were elevated only in obese animals [59]. In addition, cortisol administration under $\mathrm{PH}$ with $\mathrm{I} / \mathrm{R}$ conditions exacerbated hepatic damage and regenerative failure only in obese animals. Indeed, in obese animals, alterations in enzymatic regulation of cortisol metabolism caused cortisol accumulation in steatotic livers, whereas in lean animals, compensatory mechanisms mainly based on the clearance of hepatic cortisol were shown to prevent intrahepatic cortisol and its deleterious effects [59].

Interestingly, Bujaldon et al. recently examined the effects of vascular endothelial growth factor type A (VEGFA) on damage and regeneration in steatotic and nonsteatotic livers submitted to $\mathrm{PH}$ with I/R. The authors reported that VEGFA levels were decreased in both steatotic and nonsteatotic livers after surgery, but the exogenous VEGFA administrated was only able to reach nonsteatotic livers, reducing the incidence of postoperative complications following surgery. Unexpectedly, the authors found that circulating VEGFA was sequestered by the high circulating levels of the sFlt1 released from adipose tissue, so VEGFA could not reach the steatotic liver to exert its effects, ultimately exacerbating damage and regenerative failure [60]. Thus, the concomitant administration of VEGFA and an antibody 
against sFlt1 was required to avoid binding of sFlt1 to VEGFA. This was associated with high VEGFA levels in steatotic livers and protection against damage and regenerative failure [60] (Figure 2).

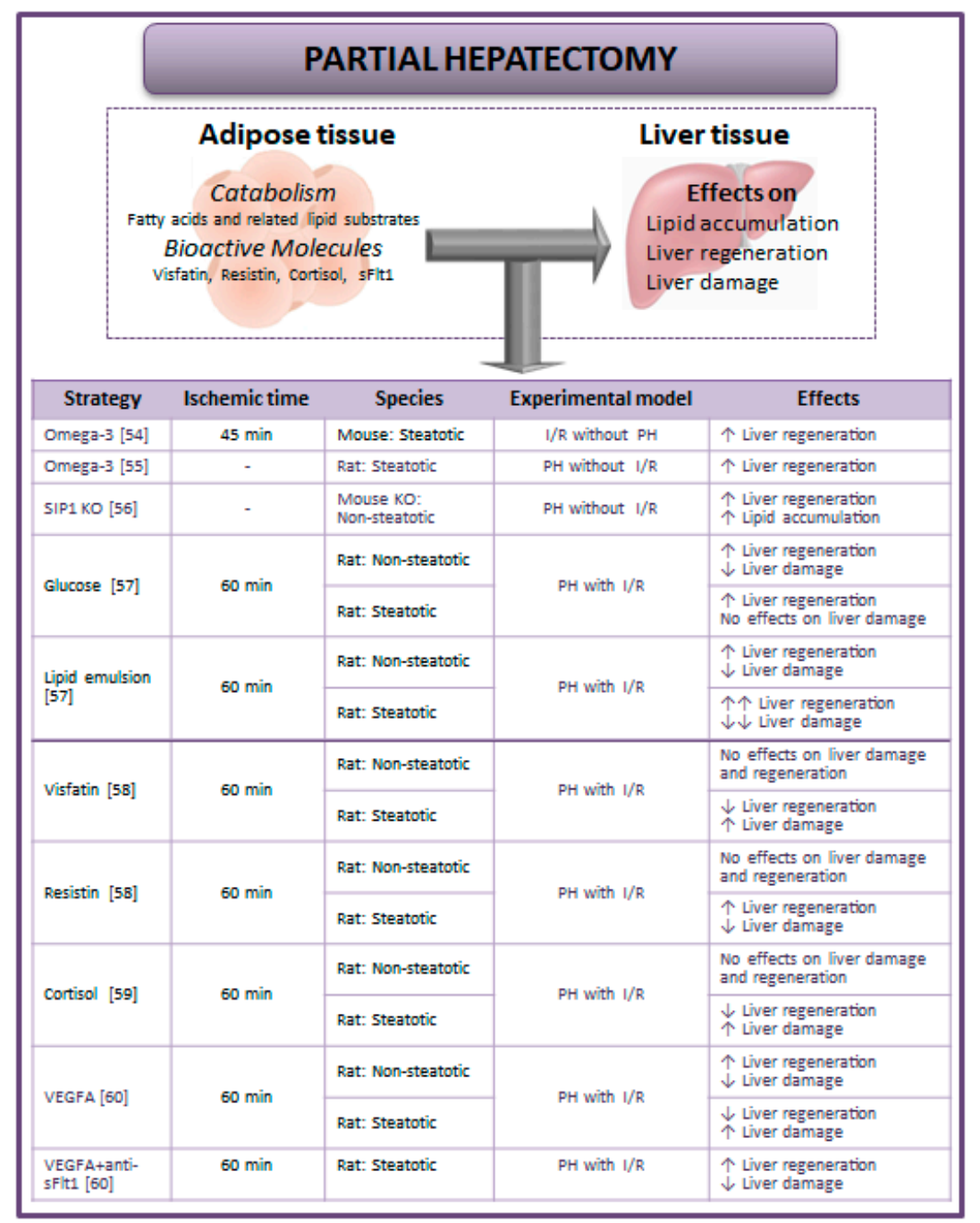

Figure 2. Strategies aimed at regulating hepatic damage and regenerative failure considering the adipose tissue-liver crosstalk during partial hepatectomy (PH) with or without I/R [54-60]. Abbreviations: I/R, ischemia-reperfusion; PH, partial hepatectomy; sFlt1, soluble form of the VEGF receptor 1; SIP1, smad interacting protein 1; VEGFA, vascular endothelial growth factor type A.

\section{Relevance of Adipose Tissue in Experimental Models of Liver Transplantation}

To our knowledge, the relevance of adipose tissue (as a source of fatty acids and related lipid substrates as well as bioactive molecules) on lipid metabolism, hepatic damage, and regeneration associated with transplantation remains to be elucidated (Figure 3). In addition, the few experimental studies on LT [61-63] have described the levels of adipokines in the liver but not in adipose tissue. In this vein, it has been demonstrated in experimental studies that adiponectin, resistin, and visfatin levels were not modified in recipients when nonsteatotic livers were subjected to transplantation, whereas in recipients of steatotic liver grafts, the presence of hepatic steatosis down-regulated both adiponectin and resistin levels under such surgical conditions, whereas no changes in visfatin levels were observed [61,62]. The role of adipose tissue as a potential source of adiponectin, resistin, or visfatin was unexplored. Nevertheless, the effects of such bioactive molecules on hepatic damage and regenerative failure were investigated in steatotic and nonsteatotic livers under PH with I/R conditions. As expected, hepatic damage in recipients of steatotic liver grafts was unaltered under 
pharmacological regulation of visfatin. However, the treatment with either exogenous adiponectin or resistin in steatotic liver grafts improved the postoperative outcomes after transplantation. In addition, the activation of adenosine monophosphate-activated protein kinase (AMPK) by pharmacological drugs such as AICAR (cell-permeable adenosine analog that is a selective activator of AMPK) or ischemic preconditioning (PC) - which increased both adiponectin and resistin in steatotic liver grafts of recipients submitted to transplantation-resulted in protection against hepatic damage [62]. In experimental models of ex vivo LT, it has been reported that the addition of leptin to preservation solutions was able to increase the signal transducer and activator of transcription-3 levels and to reduce damage in nonsteatotic grafts submitted to transplantation [63].

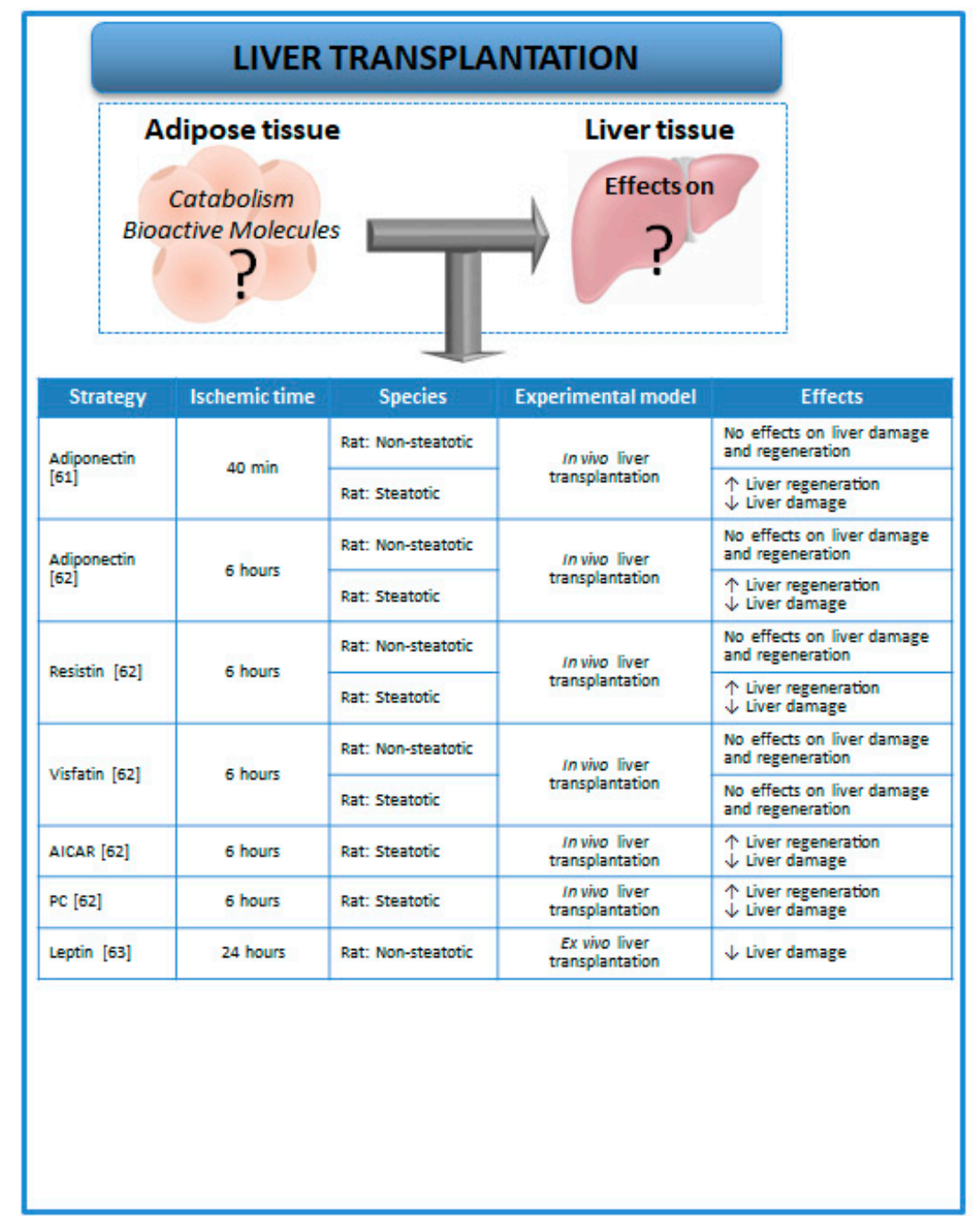

Figure 3. Strategies aimed at evaluating the role of adipokines on hepatic damage and regenerative failure in LT [61-63]. The adipose tissue-liver crosstalk during LT is still unknown. Abbreviations: AICAR, Cell-permeable adenosine analog that is a selective activator of AMPK; LT, liver transplantation; $\mathrm{PC}$, preconditioning.

All the studies mentioned above [61-63] reported the levels as well as the role of adipokines in liver grafts in experimental models of LT. However, the levels of adipokines in adipose tissue as well as the potential involvement of adipose tissue in the hepatic levels of adipokines following transplantation were not evaluated in such studies. In our view, further investigations to address this issue are of clinical and scientific relevance. In fact, in clinical practice, most of the liver grafts are obtained from brain-dead donors [64]. It is well known that brain death is associated with cerebral 
trauma and usually caused by hypoxia [65]. In addition, an experimental study aimed at evaluating the role of adipose tissue in the metabolism of rats with brain injury showed that resistin levels were increased in subcutaneous fat of rats with traumatic brain injury [66]. Moreover, it should be taken into account that adipose tissue is considered to be an important source of adipokines, such as leptin, adiponectin, and resistin, and that adipokines directly access the liver from adipose tissue through the portal vein $[9,67]$. Therefore, the relevance of adipose tissue in the hepatic damage associated with transplantation should be considered in further experimental research of LT to elucidate whether the regulation of adipose tissue functions could improve the quality of donor organs and postoperative outcomes after transplantation.

Altogether, the current knowledge emphasizes the relevance of further characterizing the role of mediators released from peripheral adipose tissue on damage and regenerative failure in both steatotic and nonsteatotic livers undergoing surgery. All of this is required to provide novel therapeutic approaches that can be transferred to clinical liver surgery and consequently increase the number of available donors for transplantation and improve recovery for patients subjected to liver resections.

\section{Relevance of Adipose Tissue in Patients Undergoing Liver Surgery}

Interestingly, the extent of visceral adipose tissue as well as serum levels of adipokines have been evaluated in patients undergoing general surgery. Nevertheless, from our knowledge, pharmacological modulation of adipokine actions has not been reported in the clinical practice of liver surgery [68-71]. Indeed, the significance of visceral adipose tissue remains controversial in the surgical setting [71].

In liver resections associated with hepatocellular carcinoma (HCC), preoperative visceral adiposity, as well as low muscularity (since obesity might be associated with a decrease in muscle mass), was closely related to postoperative death and HCC recurrence [72-74]. In addition, it has been reported that greater fat accumulation in skeletal muscle has been associated with a worse prognosis and survival after PH in patients with HCC, even with adjustment for other known predictors [75]. Moreover, prospective studies and meta-analyses have suggested that obese patients have increased risk and a poorer prognosis for many types of cancer [72-74]. All of these results in PH are in line with those observed in living donor liver transplantation (LDLT), since patients with a high degree of muscle steatosis and visceral adiposity show worse survival rates after transplantation compared with patients without obesity or with normal musculature [76]. Nevertheless, these findings are challenged by opposite observations. Indeed, preoperative abdominal computed tomographic (CT) scans in patients undergoing major hepatic resection associated with cancer suggest that obesity does not correlate with poor outcomes after major surgery [77]. Interestingly, neither preoperative visceral adiposity nor low muscularity were poor prognostic factors in patients undergoing liver resection for colorectal liver metastases [78]. In addition, some studies focused on liver resections of different cancer types showed that patients with a higher body mass index (BMI) survive longer than normal-weight patients after surgery [79-82]. It should be noted that CT measurement enables specific quantification of visceral adipose tissue, which is not reflected by BMI.

The contradictory results in clinical practice, the so-called obesity paradox, might occur due to the different methodologies used to evaluate and measure adipose tissue [71], but different types of surgery (resection vs. transplantation) as well as liver pathologies should also be noted.

Changes in adipokine levels in patients subjected to $\mathrm{PH}$ have been reported, suggesting that early-phase elevation of serum levels of hepatocyte growth factor (HGF), leptin, and macrophage colony-stimulating factor (M-CSF) could be associated with the acceleration of liver regeneration [83]. In line with this, plasmatic adipokines after LDLT have been mainly reported as biochemical markers to evaluate the risk of fibrosis progression in patients transplanted due to hepatitis C [84]. However, in these studies, the role of adipose tissue as a source of adipokines was not evaluated. 


\section{Experimental Strategies to Evaluate Adipose Tissue in Liver Surgery}

\subsection{Lipectomy}

The literature describes the surgical excision of adipose tissue (lipectomy) to evaluate the function of adipose tissue in physiological conditions and different pathologies [37,40,41]. However, few studies have attempted to discern the role of adipose tissue on adipokine levels and hepatic damage and regenerative failure in liver surgery of $\mathrm{PH}$ with $\mathrm{I} / \mathrm{R}$ [56-60], and no studies have evaluated the effects of a lipectomy in livers submitted for transplantation (Figure 4).
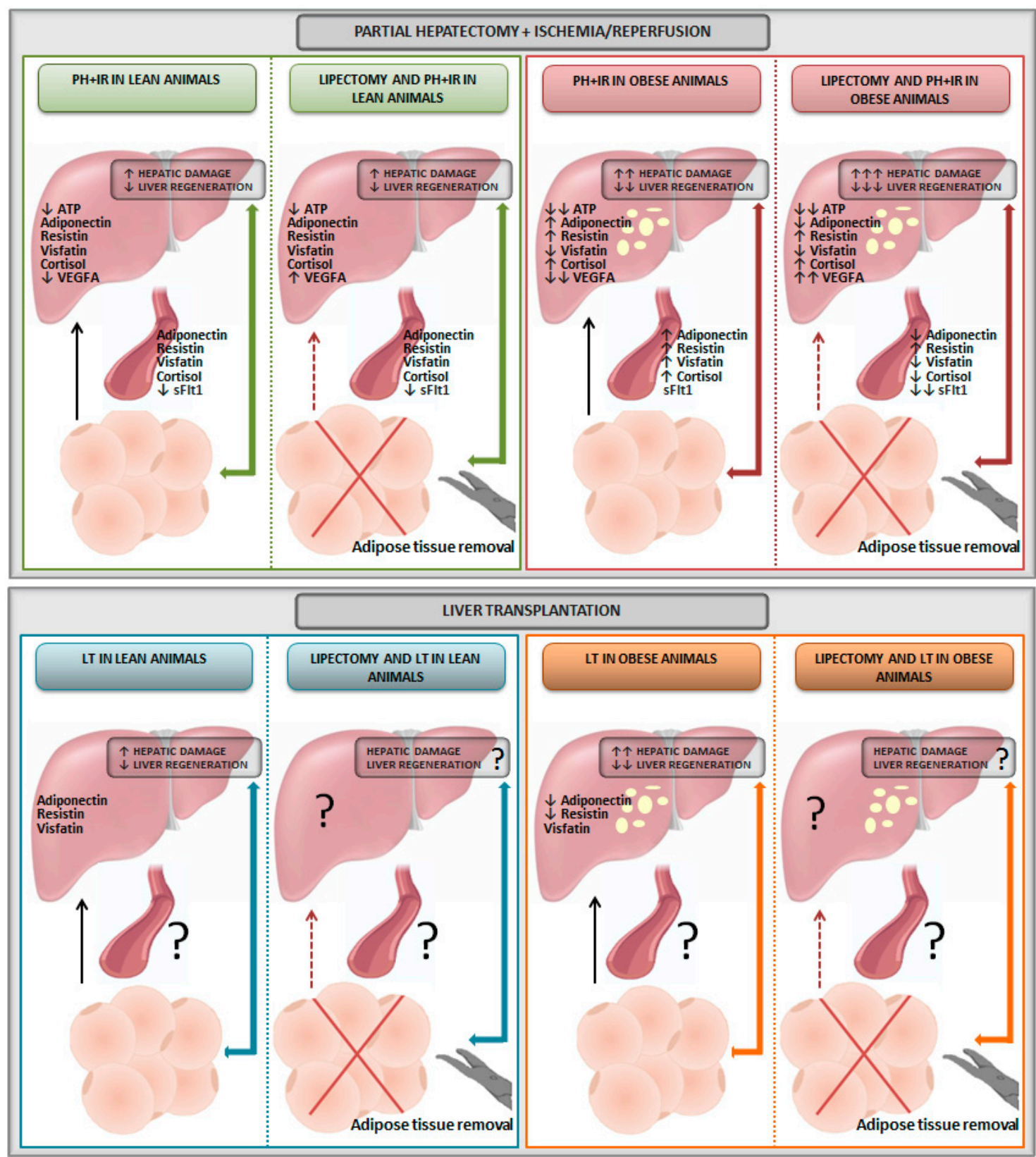

Figure 4. Schematic illustration of lipectomy effects in liver surgery. Abbreviations: ATP, adenosine triphosphate; I/R, ischemia-reperfusion; LT, liver transplantation; PH, partial hepatectomy; sFlt1, soluble form of the VEGF receptor 1; VEGFA, vascular endothelial growth factor type A.

The results obtained using lipectomy in $\mathrm{PH}$ with $\mathrm{I} / \mathrm{R}$ indicate that, in contrast with nonsteatotic livers, adipose tissue is required for liver regeneration and to reduce damage in the presence of 
steatosis [57] (Figure 4). Interestingly, adipose tissue does not seem to be an energy source for the nonsteatotic liver since ATP levels were unchanged after lipectomy [57]. Regarding adipokines, removal of adipose tissue using lipectomy in lean animals undergoing $\mathrm{PH}$ with $\mathrm{I} / \mathrm{R}$ resulted in plasmatic and hepatic levels of adiponectin, resistin, visfatin, and cortisol, similar to those observed under $\mathrm{PH}$ with I/R conditions [57-59]. The levels of sFlt1 were reduced in plasma in lean animals lipectomized and undergoing $\mathrm{PH}+\mathrm{I} / \mathrm{R}$, indicating that adipose tissue might be a potential source of sFlt1 [60]. As it has been suggested that circulating VEGFA is sequestered by the sFlt1 released by adipose tissue in lean animals in conditions of $\mathrm{PH}+\mathrm{I} / \mathrm{R}$ [60], this was associated with increases in hepatic VEGFA (Figure 4). In obese animals, the reduced hepatic ATP levels were more evident than in lean animals. However, similar to that occurring in lean animals, adipose tissue does not seem to be an energy source for the steatotic liver, since ATP levels were unchanged after lipectomy. Adipose tissue seems to be an adiponectin source for the steatotic liver, since the induction of lipectomy in obese animals reduced both plasmatic and hepatic levels of adiponectin compared with the results obtained under $\mathrm{PH}$ with $\mathrm{I} / \mathrm{R}$ conditions [57]. The contribution of adipose tissue as a source of resistin was irrelevant since obese animals undergoing PH with I/R showed high levels of plasmatic and hepatic resistin levels, whereas these resistin levels were unaltered under lipectomy conditions [58] (Figure 4). In obese animals undergoing $\mathrm{PH}$ with $\mathrm{I} / \mathrm{R}$, the visfatin levels were increased and reduced in liver and plasma, respectively. When adipose tissue was removed in obese animals undergoing $\mathrm{PH}$ with $\mathrm{I} / \mathrm{R}$, circulating visfatin levels were reduced, whereas hepatic visfatin accumulation was unaltered [58]. Thus, $\mathrm{PH}$ with $\mathrm{I} / \mathrm{R}$ induced the release of visfatin from adipose tissue to circulation and reduced the generation of visfatin by the liver [58]. In obese animals undergoing $\mathrm{PH}$ with $\mathrm{I} / \mathrm{R}$, plasmatic and hepatic cortisol levels were increased [61]. In contrast, lipectomy in obese animals reduced cortisol levels in plasma but not in the steatotic liver [59], although the potential contribution of adipose tissue in the hepatic levels of cortisol of obese animals cannot be discounted. Indeed, changes in the enzymes engaged in cortisol generation and clearance were detected in adipose tissue of obese animals undergoing PH with I/R [59]. The reduced plasmatic levels of sFlt1 in obese animals lipectomized and undergoing PH with I/R were more evident than in lean animals [60]. This increased the circulating VEGFA bioavailability and, consequently, increased the opportunity of VEGFA to be taken up by the steatotic liver [60] (Figure 4).

Reduced adiponectin and resistin levels were observed only in steatotic livers when obese animals were subjected to LT [62] (Figure 4). The role of adipose tissue on hepatic adipokine levels, hepatic damage, and regeneration following LT remains to be elucidated. In our view, given the key role of adipose tissue in steatotic and nonsteatotic livers undergoing $\mathrm{PH}$ with $\mathrm{I} / \mathrm{R}$, strategies based in the adipose tissue removal should been used to study the crosstalk liver-adipose tissue in LT, mainly in the presence of steatosis.

\subsection{Transgenic Animal Models}

The use of transgenic animal models has improved our understanding of the pathophysiology of adipose tissue. The main focus of transgenic animal models has been the expression or knockout of selected genes, specifically in adipose tissue, identifying and characterizing promoter regions that confer adipose-tissue specific expression [7]. For instance, to target both white and brown adipose tissue, the promoters for adipocyte lipid binding protein aP215 and for phosphoenolpyruvate carboxykinase are usually used, whereas to target only brown adipose tissue, the mitochondrial uncoupling protein-1 (UCP-1) promoter is used [85-87]. In our view, the potential applications of transgenic animal models with overexpression or knockout of adipose tissue-selected genes might be of scientific and clinical interest to evaluate the adipose tissue-liver axis in hepatic resections and transplantation, since in different surgical conditions, hepatic diseases might be improved by directly targeting adipose tissue, rather than liver tissue per se. 


\section{Conclusions}

The role of adipose tissue on damage and regenerative failure in experimental liver surgery depends on the type of surgical procedure ( $\mathrm{PH}$ with or without $\mathrm{I} / \mathrm{R}$ ) as well as the type of liver (steatotic versus nonsteatotic) submitted to liver surgery. This should be taken into account for the establishment of protective strategies modulating the liver-adipose tissue axis, which would be specific for each surgical procedure and type of liver, as it has been reported in the present review. Further clinical studies and appropriate methods for adipose tissue measurement will be required to elucidate the significance of visceral adipose tissue in the clinical scenario of surgical hepatic resections. The use of experimental models of lipectomy as well as transgenic animal models with expression or knockout of adipose tissue-selected genes might be of scientific and clinical relevance to elucidate the contribution of the adipose tissue-liver axis, as well as the role of adipose tissue as an energy substrate and/or a source of different adipokines and hormones in livers subjected to transplantation. This would provide novel therapeutic approaches to be transferred to clinical conditions to improve the post-transplantation outcomes and consequently increase the number of available donors for transplantation.

Funding: This research was supported by the Ministerio de Ciencia, Innovación y Universidades (RTI2018-095114-B-I00) Madrid, Spain; the European Union (Fondos Feder, 'una manera dehacer Europa'); CERCA Program/Generalitat de Catalunya; and Secretaria d'Universitats I Recerca del Departament d'Economia i Coneixement (2017 SGR-551) Barcelona, Spain.

Conflicts of Interest: The authors declare no conflict of interest.

\section{Abbreviations}

\begin{tabular}{ll} 
AICAR & Cell-permeable adenosine analog that is a selective activator of AMPK \\
AMPK & Adenosine monophosphate-activated protein kinase \\
ATP & Adenosine triphosphate \\
BMI & Body mass index \\
BMP & Bone morphogenetic protein \\
CT & Computed tomography \\
Fas/CD95 & Apoptosis antigen 1 or cluster of differentiation 95 \\
FFA & Free fatty acids \\
HCC & Hepatocellular carcinoma \\
HGF & Hepatocyte growth factor \\
I/R & Ischemia-reperfusion \\
IL & Interleukin \\
JNK1 & c-Jun N-terminal kinase-1 \\
LDLT & Living donor liver transplantation \\
LT & Liver transplantation \\
M-CSF & Macrophage colony-stimulating factor \\
NO & Nitric oxide \\
PAI-1 & Plasminogen activator inhibitor-1 \\
PC & Preconditioning \\
PH & Partial hepatectomy \\
sFlt1 & Soluble form of the VEGF receptor 1 \\
SIP1 & Smad interacting protein 1 \\
TGF- $\beta$ & Transforming growth factor- $\beta$ \\
TNF $\alpha$ & Tumor necrosis factor $\alpha$ \\
UCP-1 & Mitochondrial uncoupling protein-1 \\
VEGFA & Vascular endothelial growth factor type A \\
& \\
\hline
\end{tabular}




\section{References}

1. Kershaw, E.E.; Flier, J.S. Adipose tissue as an endocrine organ. J. Clin. Endocrinol. Metab. 2004, 89, $2548-2556$. [CrossRef] [PubMed]

2. Frühbeck, G.; Gómez-Ambrosi, J.; Muruzábal, F.J.; Burrell, M.A. The adipocyte: A model for integration of endocrine and metabolic signaling in energy metabolism regulation. Am. J. Physiol. Endocrinol. Metab. 2001, 280, E827-E847. [CrossRef] [PubMed]

3. Wang, Z.G.; Dou, X.B.; Zhou, Z.X.; Song, Z.Y. Adipose tissue-liver axis in alcoholic liver disease. World J. Gastrointest. Pathophysiol. 2016, 7, 17-26. [CrossRef] [PubMed]

4. Parker, R. The role of adipose tissue in fatty liver diseases. Liver Res. 2018, 2, 35-42. [CrossRef]

5. Large, V.; Peroni, O.; Letexier, D.; Ray, H.; Beylot, M. Metabolism of lipids in human white adipocyte. Diabetes Metab. 2004, 30, 294-309. [CrossRef]

6. Nielsen, T.S.; Jessen, N.; Jørgensen, J.O.; Møller, N.; Lund, S. Dissecting adipose tissue lipolysis: Molecular regulation and implications for metabolic disease. J. Mol. Endocrinol. 2014, 52, R199-R222. [CrossRef] [PubMed]

7. Blüher, M. Transgenic animal models for the study of adipose tissue biology. Best Pract. Res. Clin. Endocrinol. Metab. 2005, 19, 605-623. [CrossRef] [PubMed]

8. Ye, D.W.; Rong, X.L.; Xu, A.M.; Guo, J. Liver-adipose tissue crosstalk: A key player in the pathogenesis of glucolipid metabolic disease. Chin. J. Integr. Med. 2017, 23, 410-414. [CrossRef] [PubMed]

9. Schäffler, A.; Schölmerich, J.; Büchler, C. Mechanisms of disease: Adipocytokines and visceral adipose tissue-emerging role in nonalcoholic fatty liver disease. Nat. Clin. Pract. Gastroenterol. Hepatol. 2005, 2, 273-280. [CrossRef]

10. Casillas-Ramírez, A.; Mosbah, I.B.; Ramalho, F.; Roselló-Catafau, J.; Peralta, C. Past and future approaches to ischemia-reperfusion lesion associated with liver transplantation. Life Sci. 2006, 79, 1881-1894. [CrossRef]

11. Serafin, A.; Rosello-Catafau, J.; Prats, N.; Xaus, C.; Gelpi, E.; Peralta, C. Ischemic preconditioning increases the tolerance of fatty liver to hepatic ischemia-reperfusion injury in the rat. Am. J. Pathol. 2002, 161, 587-601. [CrossRef]

12. Clavien, P.; Harvey, P.; Strasberg, S. Preservation and reperfusion injuries in liver allografts. An overview and synthesis of current studies. Transplantation 1992, 53, 957-978. [CrossRef] [PubMed]

13. Huguet, C.; Gavelli, A.; Chieco, P.; Bona, S.; Harb, J.; Joseph, J.M.; Jobard, J.; Gramaglia, M.; Lasserre, M. Liver ischemia for hepatic resection: Where is the limit? Surgery 1992, 111, 251-259. [PubMed]

14. Fu, P.; Li, W. Nitric oxide in liver ischemia-reperfusion injury. In Liver Pathophysiology; Muriel, P., Ed.; Elsevier Inc.: London, UK, 2017; Volume 8, pp. 125-127.

15. Cornide-Petronio, M.E.; Jiménez-Castro, M.B.; Gracia-Sancho, J.; Peralta, C. Ischemic preconditioning directly or remotely applied on the liver to reduce ischemia-reperfusion injury in resections and transplantation. In Liver Disease and Surgery; Tsoulfas, G., Ed.; IntechOpen: London, UK, 2019; in press.

16. Gracia-Sancho, J.; Casillas-Ramírez, A.; Peralta, C. Molecular pathways in protecting the liver from ischaemia/reperfusion injury: A 2015 update. Clin. Sci. (Lond.) 2015, 129, 345-362. [CrossRef] [PubMed]

17. Pratap, A.; Panakanti, R.; Yang, N.; Lakshmi, R.; Modanlou, K.A.; Eason, J.D.; Mahato, R.I. Cyclopamine attenuates acute warm ischemia reperfusion injury in cholestatic rat liver: Hope for marginal livers. Mol. Pharm. 2011, 8, 958-968. [CrossRef] [PubMed]

18. Nadig, S.N.; Periyasamy, B.; Shafizadeh, S.F.; Polito, C.; Fiorini, R.N.; Rodwell, D.; Evans, Z.; Cheng, G.; Dunkelberger, D.; Schmidt, M.; et al. Hepatocellular ultrastructure after ischemia/reperfusion injury in human orthotopic liver transplantation. J. Gastrointest. Surg. 2004, 8, 695-700. [CrossRef] [PubMed]

19. Verran, D.; Kusyk, T.; Painter, D.; Fisher, J.; Koorey, D.; Strasser, S.; Stewart, G.; McCaughan, G. Clinical experience gained from the use of 120 steatotic donor livers for orthotopic liver transplantation. Liver Transplant. 2003, 9, 500-505. [CrossRef] [PubMed]

20. Schaubel, D.E.; Sima, C.S.; Goodrich, N.P.; Feng, S.; Merion, R.M. The survival benefit of deceased donor liver transplantation as a function of candidate disease severity and donor quality. Am. J. Transplant. 2008, 8, 419-425. [CrossRef]

21. Ploeg, R.J.; D’Alessandro, A.M.; Knechtle, S.J.; Stegall, M.D.; Pirsch, J.D.; Hoffmann, R.M.; Sasaki, T.; Sollinger, H.W.; Belzer, F.O.; Kalayoglu, M. Risk factors for primary dysfunction after liver transplantation-a multivariate analysis. Transplantation 1993, 55, 807-813. [CrossRef] 
22. Behrns, K.E.; Tsiotos, G.G.; DeSouza, N.F.; Krishna, M.K.; Ludwig, J.; Nagorney, D.M. Hepatic steatosis as a potential risk factor for major hepatic resection. J. Gastrointest. Surg. 1998, 2, 292-298. [CrossRef]

23. Safwan, M.; Collins, K.M.; Abouljoud, M.S.; Salgia, R. Outcome of liver transplantation in patients with prior bariatric surgery. Liver Transplant. 2017, 23, 1415-1421. [CrossRef] [PubMed]

24. Shook, B.; Rivera Gonzalez, G.; Ebmeier, S.; Grisotti, G.; Zwick, R.; Horsley, V. The role of adipocytes in tissue regeneration and stem cell niches. Annu. Rev. Cell Dev. Biol. 2016, 32, 609-631. [CrossRef] [PubMed]

25. Odegaard, J.I.; Chawla, A. Alternative macrophage activation and metabolism. Annu. Rev. Pathol. 2011, 6, 275-297. [CrossRef] [PubMed]

26. Khan, T.; Muise, E.S.; Iyengar, P.; Wang, Z.V.; Chandalia, M.; Abate, N.; Zhang, B.B.; Bonaldo, P.; Chua, S.; Scherer, P.E. Metabolic dys-regulation and adipose tissue fibrosis: Role of collagen VI. Mol. Cell. Biol. 2009, 29, 1575-1591. [CrossRef] [PubMed]

27. Hosogai, N.; Fukuhara, A.; Oshima, K.; Miyata, Y.; Tanaka, S.; Segawa, K.; Furukawa, S.; Tochino, Y.; Komuro, R.; Matsuda, M.; et al. Adipose tissue hypoxia in obesity and its impact on adipocytokine dysregulation. Diabetes 2007, 56, 901-911. [CrossRef] [PubMed]

28. Elias-Miro, M.; Massip-Salcedo, M.; Jimenez-Castro, M.; Peralta, C. Does adiponectin benefit steatotic liver transplantation? Liver Transplant. 2011, 17, 993-1004. [CrossRef]

29. Tilg, H.; Hotamisligil, G.S. Nonalcoholic fatty liver disease: Cytokine-adipokine interplay and regulation of insulin resistance. Gastroenterology 2006, 131, 934-945. [CrossRef]

30. Farrell, G.C. Probing Prometheus: Fat fueling the fire? Hepatology 2004, 40, 1252-1255. [CrossRef]

31. Gordon, S. Macrophage heterogeneity and tissue lipids. J. Clin. Investig. 2007, 117, 89-93. [CrossRef]

32. Wellen, K.E.; Hotamisligil, G.S. Inflammation, stress, and diabetes. J. Clin. Investig. 2005, 115, 1111-1119. [CrossRef]

33. Wellen, K.E.; Hotamisligil, G.S. Obesity-induced inflammatory changes in adipose tissue. J. Clin. Investig. 2003, 112, 1785-1788. [CrossRef] [PubMed]

34. Weisberg, S.P.; Mccann, D.; Desai, M.; Rosenbaum, M.; Leibel, R.L.; Ferrante, A.W., Jr. Obesity is associated with macrophage accumulation in adipose tissue. J. Clin. Investig. 2003, 112, 1796-1808. [CrossRef] [PubMed]

35. Duwaerts, C.C.; Maher, J.J. Macronutrients and the Adipose-Liver Axis in Obesity and Fatty Liver. Cell. Mol. Gastroenterol. Hepatol. 2019, 7, 749-761. [CrossRef] [PubMed]

36. Harman-Boehm, I.; Bluher, M.; Redel, H.; Sion-Vardy, N.; Ovadia, S.; Avinoach, E.; Shai, I.; Klöting, N.; Stumvoll, M.; Bashan, N.; et al. Macrophage infiltration into omental versus subcutaneous fat across different populations: Effect of regional adiposity and the comorbidities of obesity. J. Clin. Endocrinol. Metab. 2007, 92, 2240-2247. [CrossRef] [PubMed]

37. Nov, O.; Shapiro, H.; Ovadia, H.; Tarnovscki, T.; Dvir, I.; Shemesh, E.; Kovsan, J.; Shelef, I.; Carmi, Y.; Voronov, E.; et al. Interleukin-1 $\beta$ regulates fat-liver crosstalk in obesity by auto-paracrine modulation of adipose tissue inflammation and expandability. PLoS ONE 2013, 8, e53626. [CrossRef] [PubMed]

38. Bergman, R.N.; Kim, S.P.; Hsu, I.R.; Catalano, K.J.; Chiu, J.D.; Kabir, M.; Richey, J.M.; Ader, M. Abdominal obesity: Role in the pathophysiology of metabolic disease and cardiovascular risk. Am. J. Med. 2007, 120, S3-S8; discussion S29-S32. [CrossRef] [PubMed]

39. Kabir, M.; Catalano, K.J.; Ananthnarayan, S.; Kim, S.P.; Van Citters, G.W.; Dea, M.K.; Bergman, R.N. Molecular evidence supporting the portal theory: A causative link between visceral adiposity and hepatic insulin resistance. Am. J. Physiol. Endocrinol. Metab. 2005, 288, E454-E461. [CrossRef]

40. Sabio, G.; Das, M.; Mora, A.; Zhang, Z.; Jun, J.Y.; Ko, H.J.; Barrett, T.; Kim, J.K.; Davis, R.J. A stress signalling pathway in adipose tissue regulates hepatic insulin resistance. Science 2008, 322, 1539-1543. [CrossRef] [PubMed]

41. Wueest, S.; Rapold, R.A.; Schumann, D.M.; Rytka, J.M.; Schildknecht, A.; Nov, O.; Chervonsky, A.V.; Rudich, A.; Schoenle, E.J.; Donath, M.Y.; et al. Deletion of Fas in adipocytes relieves adipose tissue inflammation and hepatic manifestations of obesity in mice. J. Clin. Investig. 2010, 120, 191-202. [CrossRef] [PubMed]

42. Caruana, J.A.; Whalen, D.A., Jr.; Anthony, W.P.; Sunby, C.R.; Ciechoski, M.P. Paradoxical effects of glucose feeding on liver regeneration and survival after partial hepatectomy. Endocr. Res. 1986, 12, 147-156. [CrossRef] [PubMed] 
43. Nakatani, T.; Ozawa, K.; Asano, M.; Ukikusa, M.; Kamiyama, Y.; Tobe, T. Differences in predominant energy substrate in relation to the resected hepatic mass in the phase immediately after hepatectomy. J. Lab. Clin. Med. 1981, 97, 887-898. [PubMed]

44. Nakatani, T.; Yasuda, K.; Ozawa, K.; Kawashima, S.; Tobe, T. Effects of (+)-octanoylcarnitine on deoxyribonucleic acid synthesis in regenerating rabbit liver. Clin. Sci. (Lond.) 1982, 62, 295-297. [CrossRef] [PubMed]

45. Gazit, V.; Weymann, A.; Hartman, E.; Finck, B.N.; Hruz, P.W.; Tzekov, A.; Rudnick, D.A. Liver regeneration is impaired in lipodystrophic fatty liver dystrophy mice. Hepatology 2010, 52, 2109-2117. [CrossRef] [PubMed]

46. Tijburg, L.B.; Nyathi, C.B.; Meijer, G.W.; Geelen, M.J. Biosynthesis and secretion of triacylglycerol in rat liver after partial hepatectomy. Biochem. J. 1991, 277, 723-728. [CrossRef] [PubMed]

47. Brasaemle, D.L. Cell biology. A metabolic push to proliferate. Science 2006, 313, 1581-1582. [CrossRef] [PubMed]

48. Baker, N.; Garfinkel, A.S.; Schotz, M.C. Hepatic triglyceride secretion in relation to lipogenesis and free fatty acid mobilization in fasted and glucose-refed rats. J. Lipid Res. 1968, 9, 1-7. [PubMed]

49. Michalopoulos, G.K.; DeFrances, M.C. Liver regeneration. Science 1997, 276, 60-66. [CrossRef]

50. Palmero, E.; Ricart, D.; Llobera, M.; Peinado-Onsurbe, J. Partial hepatectomy and/or surgical stress provoke changes in the expression of lipoprotein lipase and actin in liver and extrahepatic tissues. Biochim. Biophys. Acta 1999, 1441, 61-68. [CrossRef]

51. Sabugal, R.; Robert, M.Q.; Julve, J.; Auwerx, J.; Llobera, M.; Peinado-Onsurbe, J. Hepatic regeneration induces changes in lipoprotein lipase activity in several tissues and its re-expression in the liver. Biochem. J. 1996, 318, 597-602. [CrossRef]

52. Shteyer, E.; Liao, Y.; Muglia, L.J.; Hruz, P.W.; Rudnick, D.A. Disruption of hepaticadipogenesis is associated with impaired liver regeneration in mice. Hepatology 2004, 40, 1322-1332. [CrossRef]

53. Kohjima, M.; Tsai, T.H.; Tackett, B.C.; Thevananther, S.; Li, L.; Chang, B.H.; Chan, L. Delayed liver regeneration after partial hepatectomy in adipose differentiation related protein-null mice. J. Hepatol. 2013, 59, 1246-1254. [CrossRef]

54. El-Badry, A.M.; Moritz, W.; Contaldo, C.; Tian, Y.; Graf, R.; Clavien, P.A. Prevention of reperfusion injury and microcirculatory failure in macrosteatotic mouse liver by omega-3 fatty acids. Hepatology 2007, 45, 855-863. [CrossRef] [PubMed]

55. Marsman, H.A.; de Graaf, W.; Heger, M.; van Golen, R.F.; Ten Kate, F.J.; Bennink, R.; van Gulik, T.M. Hepatic regeneration and functional recovery following partial liver resection in an experimental model of hepatic steatosis treated with omega-3 fatty acids. Br. J. Surg. 2013, 100, 674-683. [CrossRef] [PubMed]

56. Yang, L.; Wang, Y.; Shi, Y.; Bu, H.; Ye, F. Deletion of SIP1 promotes liver regeneration and lipid accumulation. Pathol. Res. Pract. 2016, 212, 421-425. [CrossRef] [PubMed]

57. Mendes-Braz, M.; Elias-Miró, M.; Kleuser, B.; Fayyaz, S.; Jiménez-Castro, M.B.; Massip-Salcedo, M.; Gracia-Sancho, J.; Ramalho, F.S.; Rodes, J.; Peralta, C. The effects of glucose and lipids in steatotic and nonsteatotic livers in conditions of partial hepatectomy under ischaemia-reperfusion. Liver Int. 2014, 34, e271-e289. [CrossRef] [PubMed]

58. Elias-Miró, M.; Mendes-Braz, M.; Cereijo, R.; Villarroya, F.; Jiménez-Castro, M.B.; Gracia-Sancho, J.; Guixé-Muntet, S.; Massip-Salcedo, M.; Domingo, J.C.; Bermudo, R.; et al. Resistin and visfatin in steatotic and nonsteatotic livers in the setting of partial hepatectomy under ischemia-reperfusion. J. Hepatol. 2014, 60, 87-95. [CrossRef] [PubMed]

59. Cornide-Petronio, M.E.; Bujaldon, E.; Mendes-Braz, M.; Avalos de León, C.G.; Jiménez-Castro, M.B.; Álvarez-Mercado, A.I.; Gracia-Sancho, J.; Rodés, J.; Peralta, C. The impact of cortisol in steatotic and nonsteatotic liver surgery. J. Cell. Mol. Med. 2017, 21, 2344-2358. [CrossRef] [PubMed]

60. Bujaldon, E.; Cornide-Petronio, M.E.; Gulfo, J.; Rotondo, F.; Ávalos de León, C.; Negrete-Sánchez, E.; Gracia-Sancho, J.; Novials, A.; Jiménez-Castro, M.B.; Peralta Uroz, C. Relevance of VEGFA in rat livers subjected to partial hepatectomy under ischemia-reperfusion. J. Mol. Med. (Berl.) 2019, 97, 1299-1314. [CrossRef]

61. Man, K.; Zhao, Y.; Xu, A.; Lo, C.M.; Lam, K.S.; Ng, K.T.; Ho, J.W.; Sun, C.K.; Lee, T.K.; Li, X.L.; et al. Fat-derived hormone adiponectin combined with FTY720 significantly improves small-for-size fatty liver graft survival. Am. J. Transplant. 2006, 6, 467-476. [CrossRef] 
62. Jiménez-Castro, M.B.; Casillas-Ramírez, A.; Mendes-Braz, M.; Massip-Salcedo, M.; Gracia-Sancho, J.; Elias-Miró, M.; Rodés, J.; Peralta, C. Adiponectin and resistin protect steatotic livers undergoing transplantation. J. Hepatol. 2013, 59, 1208-1214. [CrossRef]

63. Carbone, M.; Campagnolo, L.; Angelico, M.; Tisone, G.; Almerighi, C.; Telesca, C.; Lenci, I.; Moscatelli, I.; Massoud, R.; Baiocchi, L. Leptin attenuates ischemia-reperfusion injury in the rat liver. Transpl. Int. 2012, 25, 1282-1288. [CrossRef] [PubMed]

64. Jiménez-Castro, M.B.; Meroño, N.; Mendes-Braz, M.; Gracia-Sancho, J.; Martínez-Carreres, L.; Cornide-Petronio, M.E.; Casillas-Ramirez, A.; Rodés, J.; Peralta, C. The effect of brain death in rat steatotic and nonsteatotic liver transplantation with previous ischemic preconditioning. J. Hepatol. 2015, 62, 83-91. [CrossRef] [PubMed]

65. Jiménez-Castro, M.B.; Gracia-Sancho, J.; Peralta, C. Brain death and marginal grafts in liver transplantation. Cell Death Dis. 2015, 6, e1777. [CrossRef] [PubMed]

66. Zhang, R.; Wang, Z.Y.; Zhu, L.L.; Wu, F.; Chen, D.Q.; Sun, L.F.; Lu, Z.Q. Resistin expression in adipose tissues and its effect on glucose metabolism in rats with brain injury. Genet. Mol. Res. 2016, 15. [CrossRef] [PubMed]

67. Marra, F.; Bertolani, C. Adipokines in liver diseases. Hepatology 2009, 50, 957-969. [CrossRef] [PubMed]

68. Mullen, J.T.; Moorman, D.W.; Davenport, D.L. The obesity paradox: Body mass index and outcomes in patients undergoing nonbariatric general surgery. Ann. Surg. 2009, 250, 166-172. [CrossRef] [PubMed]

69. Dindo, D.; Muller, M.K.; Weber, M.; Clavien, P.A. Obesity in general elective surgery. Lancet 2003, 361, 2032-2035. [CrossRef]

70. Barone, M.; Viggiani, M.T.; Avolio, A.W.; Iannone, A.; Rendina, M.; Di Leo, A. Obesity as predictor of postoperative outcomes in liver transplant candidates: Review of the literature and future perspectives. Dig. Liver Dis. 2017, 49, 957-966. [CrossRef]

71. Hamaguchi, Y.; Kaido, T.; Okumura, S.; Kobayashi, A.; Shirai, H.; Yao, S.; Yagi, S.; Kamo, N.; Seo, S.; Taura, K.; et al. Preoperative Visceral Adiposity and Muscularity Predict Poor Outcomes after Hepatectomy for Hepatocellular Carcinoma. Liver Cancer 2019, 8, 92-109. [CrossRef]

72. Calle, E.E.; Rodriguez, C.; Walker-Thurmond, K.; Thun, M.J. Overweight, obesity, and mortality from cancer in a prospectively studied cohort of US adults. N. Engl. J. Med. 2003, 348, 1625-1638. [CrossRef]

73. Renehan, A.G.; Tyson, M.; Egger, M.; Heller, R.F.; Zwahlen, M. Body-mass index and incidence of cancer: A systematic review and meta-analysis of prospective observational studies. Lancet 2008, 371, 569-578. [CrossRef]

74. Arnold, M.; Pandeya, N.; Byrnes, G.; Renehan, A.G.; Stevens, G.A.; Ezzati, M.; Ferlay, J.; Miranda, J.J.; Romieu, I.; Dikshit, R.; et al. Global burden of cancer attributable to high body-mass index in 2012: A population-based study. Lancet Oncol. 2015, 16, 36-46. [CrossRef]

75. Kaibori, M.; Ishizaki, M.; Iida, H.; Matsui, K.; Sakaguchi, T.; Inoue, K.; Mizuta, T.; Ide, Y.; Iwasaka, J.; Kimura, Y.; et al. Effect of Intramuscular Adipose Tissue Content on Prognosis in Patients Undergoing Hepatocellular Carcinoma Resection. J. Gastrointest. Surg. 2015, 19, 1315-1323. [CrossRef] [PubMed]

76. Kamo, N.; Kaido, T.; Hamaguchi, Y.; Okumura, S.; Kobayashi, A.; Shirai, H.; Yao, S.; Yagi, S.; Uemoto, S. Impact of sarcopenic obesity on outcomes in patients undergoing living donor liver transplantation. Clin. Nutr. 2018. [CrossRef] [PubMed]

77. Morris, K.; Tuorto, S.; Gönen, M.; Schwartz, L.; DeMatteo, R.; D'Angelica, M.; Jarnagin, W.R.; Fong, Y. Simple measurement of intra-abdominal fat for abdominal surgery outcome prediction. Arch. Surg. 2010, 145, 1069-1073. [CrossRef] [PubMed]

78. Kobayashi, A.; Kaido, T.; Hamaguchi, Y.; Okumura, S.; Shirai, H.; Kamo, N.; Yagi, S.; Taura, K.; Okajima, H.; Uemoto, S. Impact of Visceral Adiposity as Well as Sarcopenic Factors on Outcomes in Patients Undergoing Liver Resection for Colorectal Liver Metastases. World J. Surg. 2018, 42, 1180-1191. [CrossRef] [PubMed]

79. Hakimi, A.A.; Furberg, H.; Zabor, E.C.; Jacobsen, A.; Schultz, N.; Ciriello, G.; Mikklineni, N.; Fiegoli, B.; Kim, P.H.; Voss, M.H.; et al. An epidemiologic and genomic investigation into the obesity paradox in renal cell carcinoma. J. Natl. Cancer Inst. 2013, 105, 1862-1870. [CrossRef] [PubMed]

80. Martin, L.; Birdsell, L.; Macdonald, N.; Reiman, T.; Clandinin, M.T.; McCargar, L.J.; Murphy, R.; Ghosh, S.; Sawyer, M.B.; Baracos, V.E. Cancer cachexia in the age of obesity: Skeletal muscle depletion is a powerful prognostic factor, independent of body mass index. J. Clin. Oncol. 2013, 31, 1539-1547. [CrossRef] [PubMed] 
81. Schlesinger, S.; Siegert, S.; Koch, M.; Walter, J.; Heits, N.; Hinz, S.; Jacobs, G.; Hampe, J.; Schafmayer, C.; Nöthlings, U. Postdiagnosis body mass index and risk of mortality in colorectal cancer survivors: A prospective study and metaanalysis. Cancer Causes Control 2014, 25, 1407-1418. [CrossRef] [PubMed]

82. Amptoulach, S.; Gross, G.; Kalaitzakis, E. Differential impact of obesity and diabetes mellitus on survival after liver resection for colorectal cancer metastases. J. Surg. Res. 2015, 199, 378-385. [CrossRef]

83. Matsumoto, K.; Miyake, Y.; Umeda, Y.; Matsushita, H.; Matsuda, H.; Takaki, A.; Sadamori, H.; Nouso, K.; Yagi, T.; Fujiwara, T.; et al. Serial changes of serum growth factor levels and liver regeneration after partial hepatectomy in healthy humans. Int. J. Mol. Sci. 2013, 14, 20877-20889. [CrossRef] [PubMed]

84. Veldt, B.J.; Poterucha, J.J.; Watt, K.D.; Wiesner, R.H.; Hay, J.E.; Rosen, C.B.; Heimbach, J.K.; Janssen, H.L.; Charlton, M.R. Insulin resistance, serum adipokines and risk of fibrosis progression in patients transplanted for hepatitis C. Am. J. Transplant. 2009, 9, 1406-1413. [CrossRef] [PubMed]

85. Short, M.K.; Clouthier, D.E.; Schaefer, I.M.; Hammer, R.E.; Magnuson, M.A.; Beale, E.G. Tissue-specific, developmental, hormonal, and dietary regulation of rat phosphoenolpyruvate carboxykinase-human growth hormone fusion genes in transgenic mice. Mol. Cell. Biol. 1992, 12, 1007-1020. [CrossRef] [PubMed]

86. Cassard-Doulcier, A.M.; Gelly, C.; Fox, N.; Schrementi, J.; Raimbault, S.; Klaus, S.; Forest, C.; Bouillaud, F.; Ricquier, D. Tissue-specific and beta-adrenergic regulation of the mitochondrial uncoupling protein gene: Control by cis-acting elements in the 50-flanking region. Mol. Endocrinol. 1993, 7, 497-506. [PubMed]

87. Valet, P.; Tavernier, G.; Castan-Laurell, I.; Saulnier-Blache, J.S.; Langin, D. Understanding adipose tissue development from transgenic animal models. J. Lipid Res. 2002, 43, 835-860. [PubMed]

(C) 2019 by the authors. Licensee MDPI, Basel, Switzerland. This article is an open access article distributed under the terms and conditions of the Creative Commons Attribution (CC BY) license (http://creativecommons.org/licenses/by/4.0/). 